\title{
Comparison of Egyptian and English Mediation Procedures in Construction
}

\author{
Ahmed S. Swelam ${ }^{1}$, Adel I. Eldosouky ${ }^{2}$, and Tamer M. El Korany ${ }^{3}$ \\ ${ }^{1}$ Corresponding Author: ahmed_swelam27@yahoo.com \\ 1, 2, 3 Structural Department, Faculty of Engineering, Tanta University, Egypt
}

\begin{abstract}
The mediation process is the parties' will to the dispute to reach an amicable, non-binding settlement to end their dispute. The Egyptian legislature adopted the idea of issuing a draft law on mediation in civil and commercial matters to settle disputes between the parties, whether before the litigation stage or after appearing before the courts. The Egyptian Ministry of Justice held many community dialogue sessions to find the final version of the draft law. However, the concerned authorities have not issued the law until writing this paper. This research aims to compare and analyze the Egyptian mediation procedures and the British mediation procedures to improve, develop, and enhance the Egyptian ones especially the draft law as well as overcoming the obstacles that hinder the spread of mediation. On the one hand, presenting the Egyptian procedures in the draft mediation law and the rules of the Cairo Regional Center for International Commercial Arbitration, CRCICA. On the other hand, the British procedures represented in the Institute of Civil Engineers' mediation rules, ICE.
\end{abstract}

Keywords: mediation, draft law, CRCICA, ICE, barriers, and settlement.

\section{INTRODUCTION}

Mediation is a form of assisted negotiation since the mediator can help the parties communicate more effectively, which in turn help settle the dispute among them. Mediation is the main form of helping the parties unable to resolve a dispute using a neutral and impartial third party to settle their disputes. There are three types of mediation, namely, ad-hoc mediation, institutional mediation and judicial mediation. There is no integrated law for judicial mediation in Egypt, and therefore courts or individuals may not resort to judicial mediation until the mediation law is issued [29].

Mediation is used in construction disputes in England, and the law surrounding it is relatively well established. Mediation is recommended as the most desirable approach to resolving disputes without affecting the relationship between the parties. Although a court cannot force parties to settle their disputes by mediation, the Civil Procedure Rules, Technology and Construction Court Guide, and Pre-Action Protocol for Construction and Engineering Disputes vigorously promote the practice [28]. Nevertheless, some obstacles hinder the spread of mediation, which will be addressed later in this paper. The objectives of this research are: 1) presenting and discussing some articles of the Egyptian draft mediation law and the mediation rules of the Cairo Regional Center for International Commercial Arbitration, CRCICA; 2) comparison between the Egyptian procedures represented in the draft mediation law and the rules of CRCICA and the British procedures represented in the Institute of Civil Engineers' mediation rules, ICE. To achieve the above objectives, the remainder of the paper is structured as follows. Firstly, literature is reviewed. Secondly, introduction of mediation in the UK is presented.
The Egyptian draft mediation law for settling civil and commercial disputes is given. Comparison between CRCICA mediation rules and the Egyptian draft mediation law is then carried out. Summary and conclusions are drawn in the last section.

\section{LITERATURE REVIEW}

It is recommended that project participants at an early stage of the project use strategic mediation methods to reduce the risk of conflicts [22]. The most familiar and accustomed debate settlement approaches in Egypt's construction projects are negotiation, mediation and arbitration sequentially [10].

(Brooker, 1997) brought about research aiming to explore the Alternative Dispute Resolution, ADR, in the construction industry and the elements that affected the parties' preferences. According to this study, it was concluded that defendants believed that conciliation, mediation and adjudication are fit for minor claims, but arbitration and litigation are appropriate for more significant claims [3].

(Remond, 2008) presented that construction adjudication is an interim fast track method of resolving disputes under construction contracts. Despite its 'rough and ready' nature, construction adjudication has become the principal means of resolving disputes in the construction industry in the UK. Adjudication in the UK emanates from the Latham Report 'Constructing the Team' in 1994. The basis for adjudication is statutory the Housing Grants Construction and Regeneration Act 1996 as amended. This Act provides that any party to a dispute arising from a construction contract has the right to refer the dispute to adjudication [24].

(Pickavance, 2016) presented that statutory, contractual, and ad hoc adjudication are the three types of adjudication. If the contract between the parties falls within the Act's scope, the statutory adjudication regime will apply. A contractual adjudication is where the contract does not fall within the scope of the Act. However, the parties have nevertheless agreed to adjudicate their disputes by inserting an adjudication procedure into the contract. An ad hoc adjudication is when the parties have agreed to submit their dispute to adjudication. They give an adjudicator ad hoc jurisdiction to decide the dispute in circumstances where the Act does not apply and where there is no pre-existing contractual agreement to adjudicate. The 1996 Act is one of the most important pieces of legislation for the building and civil engineering industry. In addition to primary legislation, each UK jurisdiction has enacted secondary legislation. In England and Wales, the legislation is called the Scheme for Construction Contracts [26].

Government agencies, professional bodies, business bodies, and academic institutions must develop and use mediation in 
the construction industry. Additional steps, such as setting up a construction court, are required to support and encourage mediation [19]. The mediation field will continue to thrive if the concerned authorities can offer the market new talent regarding mediators rather than just the same old faces. Still, that talent must be of high quality [5].

The mediations are being conducted at the request of the parties. However, mediations occur at several points throughout the litigation process, including pleadings, disclosure, payment in, and shortly before trial [13].

If one party offers mediation, and the other refuses, the party refusing mediation must have good and sufficient reasons for refusing; otherwise, the party will be penalized in costs. A party may refuse mediation if it has no reasonable prospect of success from an objective point of view. The refusal, however, is a high-risk course; the party refusing can be penalized if the Court finds a genuine prospect. Forcing unwilling parties to refer their disputes to mediation imposes a barrier to their right to access the Court, which is unacceptable [14].

To benefit from the maximum cost-saving that mediation can offer, it should be undertaken at the earliest possible opportunity, before time and costs have been spent preparing extensive documentation. Mediation agreements can create a legally binding contract. The benefit of the creative solutions that mediation offers has been proven to be highly beneficial to the construction industry, where disputes are rarely clear-cut and flexible about solutions or actions required [15].

There are two types of mediation; evaluative and facilitative. Facilitative mediation is often characterized as interest-based. A facilitative mediator should allow parties to express their sides of the issues and offer them an opportunity to be heard. He would engage in the following tasks: asking questions and helping the parties develop proposals. On the other hand, evaluative mediation focuses on the legal rights of the parties. An evaluative mediator focuses on the underlying substance and cause of a dispute [25].

(Gaitskell, 2016) presented that a facilitative approach to mediation is when the mediator does not give opinions or pass judgment on the parties' respective positions or cases but seeks to bring the parties together to resolve their dispute without considering or adjudicating the underlying rights and liabilities of the parties in any detail, which meets the parties' real needs. In contrast, evaluative mediation will permit the parties to investigate through the mediator the respective rights and liabilities of the parties. The mediator may give his opinion on the merits of the dispute or a part of it. It is a matter for the mediator to assess which approach is most effective for any particular dispute and the parties to it [12].

(Fisher, 2017) presented that arbitrations in England, Wales and Northern Ireland are based on party autonomy which means an organization's right to be independent and govern itself. Besides, the parties have the capacity under their laws to conclude the arbitration agreement. Nevertheless, on the negative side, the research claimed that arbitration has drawbacks because it is considered to be expensive and timewasting [11].

(Rajoo, 2010) pointed out that there are two types of arbitration; governed by an institution or ad hoc. Each arbitral institution has its own rules, which are available to the user community. There are merits and demerits of each method. On the one hand, arbitration's prime benefit through institutions is integrating rules in a guidebook. Another attraction of using this approach is that institutional arbitration brings professional arbitrators to conduct the arbitration. However, it is costly as a consequence of the supervisory expenditures owed by the institution. Alternatively, a noticeable positive aspect of using Ad-hoc arbitration is that it can be designed to fulfil the parties' goals [23].

Table I: Comparison between judicial mediation and the judiciary

\begin{tabular}{|c|c|c|}
\hline $\begin{array}{c}\text { Face of } \\
\text { Comparison }\end{array}$ & Judicial mediation & The judiciary \\
\hline $\begin{array}{l}\text { The settlement } \\
\text { operator }\end{array}$ & $\begin{array}{l}\text { A mediator appointed by } \\
\text { the judge }\end{array}$ & The judge \\
\hline Basic principle & $\begin{array}{c}\text { Based on interests and } \\
\text { continuation of } \\
\text { relationships }\end{array}$ & Based on rights and law \\
\hline $\begin{array}{l}\text { Consensual } \\
\text { principle }\end{array}$ & $\begin{array}{l}\text { Smooth procedures that } \\
\text { adapt to the will of the } \\
\text { parties }\end{array}$ & Binding procedures \\
\hline $\begin{array}{l}\text { Settlement } \\
\text { period }\end{array}$ & $\begin{array}{l}\text { Very short (from } 1 \text { to } 6 \\
\text { months) }\end{array}$ & $\begin{array}{c}\text { Extends for more than } 3 \\
\text { years }\end{array}$ \\
\hline Confidentiality & $\begin{array}{l}\text { The most important } \\
\text { feature }\end{array}$ & $\begin{array}{c}\text { Characterized by the } \\
\text { openness of sessions and } \\
\text { pronouncement of } \\
\text { judgments }\end{array}$ \\
\hline Jurisdiction & $\begin{array}{c}\text { Limited to specific } \\
\text { disputes } \\
\end{array}$ & $\begin{array}{l}\text { General jurisdiction over } \\
\text { all disputes } \\
\end{array}$ \\
\hline $\begin{array}{l}\text { Participation of } \\
\text { the parties in } \\
\text { resolving the } \\
\text { conflict }\end{array}$ & $\begin{array}{c}\text { Provides an opportunity } \\
\text { for the parties to } \\
\text { negotiate and reach a } \\
\text { solution }\end{array}$ & $\begin{array}{l}\text { The court is composed of } \\
\text { judges; the parties have no } \\
\text { role in appointing them }\end{array}$ \\
\hline $\begin{array}{l}\text { End of the } \\
\text { settlement } \\
\text { process }\end{array}$ & $\begin{array}{l}\text { It ends with the parties } \\
\text { signing the settlement } \\
\text { agreement } \\
\text { (All parties are satisfied } \\
\text { and winners) }\end{array}$ & $\begin{array}{l}\text { Parties have no role in } \\
\text { drafting the final judgment } \\
\text { (Winning parties and } \\
\text { losing parties) }\end{array}$ \\
\hline
\end{tabular}

\section{COMPARISON BETWEEN JUDICIAL MEDIATION AND THE JUDICIARY}

Judicial mediation and the judiciary agree that each of them is one of the means to end the dispute by resorting to the judicial authority whose task is to settle the dispute through the courts. The mediator and the judge share many common characteristics, including impartiality, experience, and integrity. However, the judiciary's role differs from mediation in several matters mentioned in table I [2]. It is often easy to want to sue the other party in courts; however, going through a court trial can be a lengthy and costly process. Judicial mediation is one of the alternative dispute resolutions, ADR, used by the state courts to help parties resolve disputes easily without the need for a trial. Mediation is conducted at the state courts as part of the pre-trial case management process. Mediation allows the disputing parties more control over the outcome and reduces the time and costs involved in resolving the dispute. Thus, judicial mediation is better than the judiciary.

\section{COMPARISON BETWEEN MEDIATION AND ARBITRATION}

Mediation and arbitration require the assistance of a third party. However, mediation differs from arbitration in some matters mentioned in table II [16]. As is evident from the table that mediation can improve communication, negotiation and 
build consensus. The mediation process is confidential, voluntary, flexible, and unlike a court, there is no imposed decision: you retain ownership of and responsibility for any settlement that is reached [20].

Table II: Comparison between mediation and arbitration

\begin{tabular}{|c|c|c|}
\hline $\begin{array}{c}\text { Face of } \\
\text { Comparison }\end{array}$ & Mediation & Arbitration \\
\hline The final result & $\begin{array}{l}\text { It becomes binding with the } \\
\text { consent of both parties } \\
\text { (Compromise) }\end{array}$ & $\begin{array}{l}\text { Final and binding } \\
\text { (Award) }\end{array}$ \\
\hline $\begin{array}{l}\text { The role of } \\
\text { the } \\
\text { mediator/arbitrator }\end{array}$ & $\begin{array}{l}\text { It is not to broker a } \\
\text { settlement between the } \\
\text { parties but to assist them in } \\
\text { negotiating their settlement }\end{array}$ & $\begin{array}{l}\text { Listening to facts and } \\
\text { evidence and then } \\
\text { issuing the award }\end{array}$ \\
\hline Impact & $\begin{array}{l}\text { The agreement to mediate } \\
\text { does not prevent any of the } \\
\text { litigants from resorting to } \\
\text { the court }\end{array}$ & $\begin{array}{l}\text { The agreement on } \\
\text { arbitration precludes } \\
\text { submitting the dispute to } \\
\text { the judiciary to consider } \\
\text { its subject matter }\end{array}$ \\
\hline The participants & $\begin{array}{l}\text { The parties or legal } \\
\text { representatives and the } \\
\text { mediator }\end{array}$ & $\begin{array}{l}\text { The parties or legal } \\
\text { representatives, } \\
\text { arbitrators, witnesses } \\
\text { and experts }\end{array}$ \\
\hline $\begin{array}{l}\text { Conduct of the } \\
\text { proceedings }\end{array}$ & $\begin{array}{l}\text { Meeting the parties with the } \\
\text { mediator until reaching a } \\
\text { satisfactory solution for all } \\
\text { parties. The mediator can } \\
\text { communicate privately and } \\
\text { separately with each party; } \\
\text { this is something not } \\
\text { permitted to an arbitrator. }\end{array}$ & $\begin{array}{l}\text { Includes submitting the } \\
\text { case documents, hearing } \\
\text { the parties and calling } \\
\text { witnesses to reach a } \\
\text { final and binding award }\end{array}$ \\
\hline $\begin{array}{l}\text { The relationship } \\
\text { between the } \\
\text { parties }\end{array}$ & Preserves relationships & $\begin{array}{l}\text { It doesn't necessarily } \\
\text { maintain relationships }\end{array}$ \\
\hline
\end{tabular}

The Mediation Proceeding enables the mediator to contact each party privately and separately, without revealing what was said to the other party; an adjudicator or an arbitrator cannot do so. The information given to the mediator is not given under oath or affirmation. The mediator is not bound by natural justice rules or the rules of evidence [2]. The difference between the mediation and arbitration processes can also be presented in Figures 1 and 2.

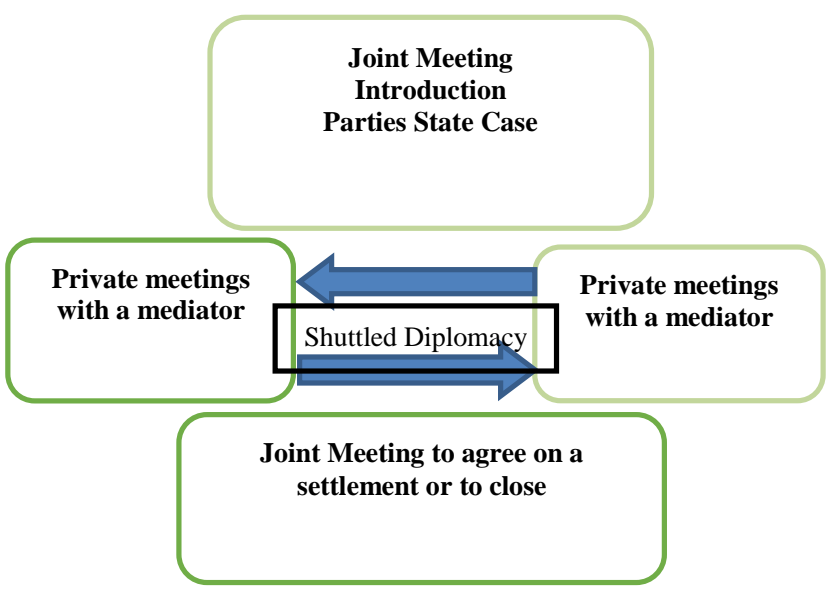

Fig. 1: Mediation Process

\section{INTRODUCTION OF MEDIATION IN THE UK}

Internationally, the benefits of mediation are becoming increasingly known as a dispute resolution technique. In the commercial sector, especially concerning the construction industry, the ICE updated its mediation procedure in 2012. The guidelines for dealing with these disputes are defined in the contract concerned by the terms of the dispute settlement clause. In the UK, mediation has become an increasingly popular and facilitative procedure in which the mediator neers (ICE) in London or if they can agree on the mediator's identity, contact them directly.

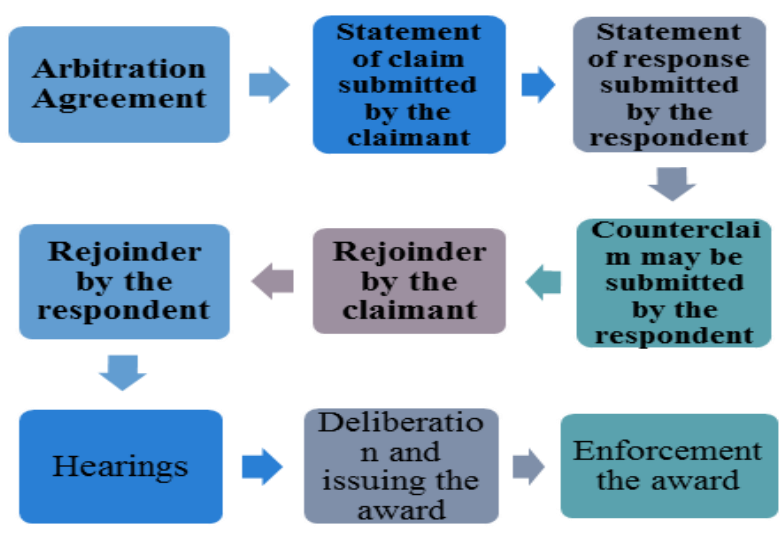

Fig. 2: Arbitration Process

The outcome of mediation is not imposed and only becomes binding with both parties' consent [18].There are several approved mediation providers in the UK, such as the Chartered Institute of Arbitration (CIArb), the Centre for Effective Dispute Resolution (CEDR), the Alternative Dispute Resolution Group (ADR Group) and the Institution of Civil Engineers (ICE). Some of the chambers of construction specialists and engineering barristers also provide mediation services whereby a member of the chambers is appointed as a mediator. Other facilities can be provided for the mediation by these chambers [12]. In this paper, the focus will be on the ICE mediation rules.

The mediator is the process manager. He monitors the process and assists the parties in resolving their disputes. In order to encourage complete, honest discussion, the mediator must win the trust of the parties. A thorough analysis of the problems will assist in the creation of solutions. Fig. 3 shows some of the required and essential skills that the mediator must perform and characterized by the mediator to succeed in his task. Generally, there are three primary phases to mediate; Premediation, Mediation, and Post-mediation. Fig. 4 clarifies the goal of each of the three stages. Here, it is worth noting that it does not mean that the mediation was not successful if the parties do not settle.

The parties may be more familiar with their dispute, leading to further efficiencies in the dispute resolution [18]. In other words, the majority of mediations will follow a threestage process. The basic process include: exploration, bargaining and conclusion. The exploration phase is the opportunity for the mediator to build rapport with the parties and gain the parties' confidence and trust. The exploration phase allows the mediator to explore matters so that they can be addressed during the remainder of the mediation. The bargaining phase is when the possible terms upon which a settlement may be reached can be discussed in detail. That 
stage will continue until the parties agree or it is clear that they will not succeed in concluding an agreement. The mediator will have studied the real needs of the parties and will have identified possible emotional blockages. After the parties have settled, the final stage arises. The parties shall be responsible for drafting a formal settlement agreement in the conclusion phase [12].



Fig. 3: The Mediator's Skills and Role [18]

\section{Barriers to Construction Mediation in the UK}

The concerns relating to the growth of mediation have been ignored. It is crucial to shed light on the barriers that discourage mediation in resolving construction industry disputes, particularly in the UK. What prevents people from mediating the conflict and how the factors influence the mediation process are essential to answer? It is advisable to obtain an in-depth understanding of obstacles to the efficacy of media use in the UK construction industry to guarantee that the mediation process is fruitful and efficient and to achieve its intended target [28].

There were five categories of obstacles that restrict the spread of building mediation in the UK. 1) There is a lack of social consciousness. It explains how and why mediation was incorrectly taken in the construction sector, 2) Culture of conflict. It concerns the attitudes of individuals participating in the mediation conflict, 3) Insufficient preparation and planning. It involves the understanding of the advantages and methods of mediation, 4) challenges to the process. 5) Lack of security and confidence. It describes misjudges during the mediation process [1].

There are common reasons mediations fail, such as (a) the disputant does not have the responsibility, because this is a non-binding procedure, to resolve the dispute; (b) the mediator or disputant does not adequately prepare for mediation; (c) the mediator, attorneys, and disputants do not foresee any potential issues, leading to failure to resolve the dispute.; (d) the mediator is inappropriate! e) there is not enough settlement authority in the parties involved in mediation; f) the settlement in mediation is not well reported [21].

There are barriers to the greater use of meditation in the English construction industry. Those include 1) belief that other party would not take part in good faith, in other words, lack of trust that the other party will act faithfully and the dispute will be compromised; 2) the case type not appropriate for mediation; 3) belief that negotiation was capable of settling the case, in other words, misconceptions that mediation is inappropriate or is not capable of solving the dispute; and 4) lack of detailed understanding and awareness of mediation process [27].

\section{Barriers to Construction Mediation in Egypt}

Most obstacles that impede the spread of mediation in Egypt are the same as those that hinder its spread in the United Kingdom.

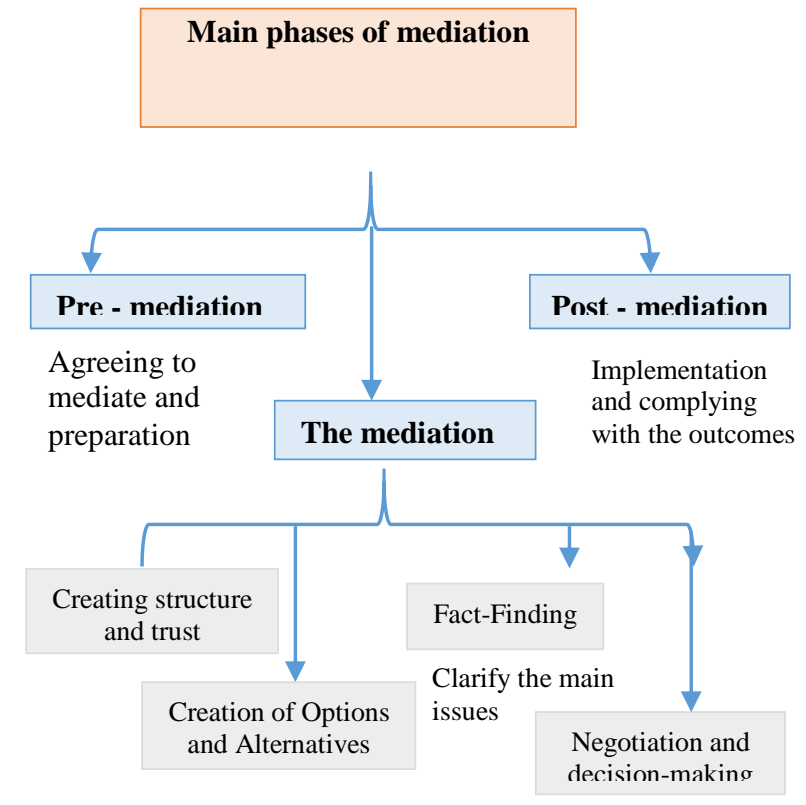

Fig. 4: Main Phases of mediation [4]

For example, non-trained mediators' choice, the misunderstanding about the non-binding nature of mediation, and lack of awareness of what mediation means. Additionally, lawyers opposing mediation, which means that some lawyers for the parties resist the mediation process because it takes a short period, which means that their fees will not be large.

\section{THE EGYPTIAN DRAFT MEDIATION LAW FOR SETTLING CIVIL AND COMMERCIAL DISPUTES}

It is a draft under study by the Egyptian Ministry of Justice and Parliament, and it has not been approved yet. Some of its articles will be explained and clarified below. It must be noted that all the presented articles here of the Egyptian draft mediation law for settling civil and commercial disputes have been obtained from [2] except article 23 has been obtained from [30].

Article 1-B

Agreed mediation is resorted to by the parties' agreement after the dispute has occurred to choose the mediator enrolled in the mediator list at the Ministry of Justice or a specialized institution.

Article 1-E

In compulsory judicial mediation, the mediating judge is appointed through the Mediation Department, the Judicial Mediation Department in every court of the first instance, from among its members. The case file is referred to him to initiate 
the mediation procedures. Mediation judges belonging to this administration are chosen by the first instance court's president or the president of the economic court after approval of the General Assembly for a one-year renewable.

\section{Article 1-H}

To appoint a mediator in the agreed mediation, the mediation department has the choice between either appointing a mediator from the list of private mediators, according to a decision issued by the Minister of Justice under the criteria that he specifies or selecting a mediator judge from the administration's judges according to the will of the parties.

\section{General Provisions}

Article 2

The legislator was concerned with the importance of the impartiality of the mediator. Impartiality of the third party in any dispute is a precondition for mediation's success because the trust of the conflicting parties in the mediator is the essential factor for the continuation and success of the mediation process. What is meant by the mediator's impartiality is to stand at the same distance from the disputants and consider the principle of equality between them.

\section{Article 3}

Mediator independence includes not being subject to external pressures or influences that could affect his profession, whether the mediator's interest is material or moral. Here, a distinction must be clarified between impartiality and independence, as impartiality is a psychological and emotional position, while independence is a realistic legal position.

\section{Agreed Mediation}

Article 23

The mediator is chosen and named by the parties' agreement, from among the mediators registered in the mediators' list of the competent mediation administration in its area the place of writing the mediation agreement is located. Article 29

The mediator is appointed by agreement of the parties from the list of private mediators. However, in case of disagreement, the mediation department will select a private mediator from the list. The legislator allowed both parties to a grievance against the private or judicial mediator's appointment to the mediation department director.

\section{Judicial Mediation}

Article 39

This article explains that cases with a value of over 100,000 Egyptian pounds and unassessed cases are referred to compulsory judicial mediation. The Director of the Mediation Department determines the issues that fall within the jurisdiction of the Mediation Department.

Article 42

The main goal in judicial mediation is to save time, money, and effort on the litigants. There is no doubt that slow justice is injustice, and speedy dispute resolution has become a basic requirement. Therefore, the Egyptian draft mediation law has defined the mediation period to be one month from the date the dispute is referred to. It may be extended for another month. The draft mediation law has not provided for the renewal of the mediation period.
In 2019, the Constitutional and Legislative Affairs Committee of the House of Representatives approved some amendments to the draft law: 1) the concept of private mediation has been added as mediation carried out by a private mediator from among the private mediators. They practice mediation for the amicable settlement of the dispute. 2) The mediation fees, including settlement application fees, and administrative expenses, were also determined. 3) Article 42 has been amended for mediation to end within a maximum period of 3 months from the first session's date, instead of two months, unless the parties spend another period. As for judicial mediation, the three months may be extended by a decision of the Director of the Mediation Department, based on the parties' agreement. Lastly, the amendments specified the cases of termination of private and judicial mediation. As for private mediation, it ends with the issuance of the report of the amicable settlement with the signature of the parties to the dispute, or when one of the parties to the dispute expresses in writing his desire to terminate it, or when the friendly settlement is not possible, or there is no consensus on choosing the mediator. Concerning the judicial mediation, it ends with the parties' objection to the Director of the Mediation Department's decision regarding the choice of the mediator or the death or loss of capacity of one of the parties to the dispute [9].

\section{Main Phases of Mediation}

The stages of mediation can be summarized in four main steps, as shown in Fig. 5. Stage one is essential for establishing a relationship that will facilitate the rest of the mediation process. Stage two in which the mediator is chosen to play the appropriate position in compliance with the requisite qualifications. Stage three in which the mediator assists participants in understanding their areas of consensus and disagreement. Stage four in which mediation parties seek to enforce the terms of their mediated agreement [17].



Fig. 5: Main Steps of Mediation

\section{COMPARISON OF ICE AND CRCICA MEDIATION RULES}

CRCICA, The Cairo Regional Centre for International Commercial Arbitration, is an independent international organization established in 1979. CRCICA's Mediation Rules were issued in March 1990. The present CRCICA Mediation Rules have entered into force as from 1 January 2013. The CRCICA Rules provide little guidance regarding the mediator's role and the conduct of the mediation proceedings. 
In contrast, under ICE Mediation Procedure, the mediator may visit the site and investigate the dispute's facts and circumstances [17].

Table III: Mediation Rules of ICE and CRCICA

\begin{tabular}{|c|c|c|}
\hline $\begin{array}{c}\text { Face of } \\
\text { Comparison }\end{array}$ & ICE Mediation Rules & $\begin{array}{l}\text { CRCICA Mediation } \\
\text { Rules }\end{array}$ \\
\hline \multirow{2}{*}{$\begin{array}{l}\text { The Primary } \\
\text { Objective }\end{array}$} & \multicolumn{2}{|c|}{$\begin{array}{l}\text { Achieving a settlement of the dispute by } \\
\text { agreement between the parties }\end{array}$} \\
\hline & Rule (1.2) & Article (2) \\
\hline \multirow[t]{2}{*}{ Confidentiality } & \multicolumn{2}{|c|}{$\begin{array}{l}\text { The mediator shall maintain the confidentiality of } \\
\text { all information }\end{array}$} \\
\hline & Rule (1.3) & Article (11) \\
\hline \multirow{2}{*}{$\begin{array}{l}\text { Notice of } \\
\text { Mediation }\end{array}$} & \multicolumn{2}{|c|}{$\begin{array}{c}\text { In the absence of a prior agreement between the } \\
\text { parties }\end{array}$} \\
\hline & Rule (2.1) & Article (3.2) \\
\hline \multirow[t]{2}{*}{$\begin{array}{c}\text { Mediation } \\
\text { Commencement }\end{array}$} & $\begin{array}{l}\text { After the appointment of } \\
\text { the mediator }\end{array}$ & $\begin{array}{l}\text { When the other party } \\
\text { accepts in writing the } \\
\text { mediation request }\end{array}$ \\
\hline & Rule (4.2) & Article (3.4) \\
\hline \multirow[t]{2}{*}{ Representation } & \multicolumn{2}{|c|}{$\begin{array}{l}\text { Each party may be represented by one or more } \\
\text { persons chosen by it }\end{array}$} \\
\hline & Rule (4.4) & Article (5) \\
\hline \multirow{2}{*}{$\begin{array}{l}\text { Appointment of } \\
\text { the Mediator }\end{array}$} & \multicolumn{2}{|c|}{$\begin{array}{l}\text { Within } 14 \text { days of the agreement by the } \\
\text { Institution/Centre }\end{array}$} \\
\hline & Rule (3.1) & Article (6.2) \\
\hline \multirow{2}{*}{$\begin{array}{l}\text { Resignation/ } \\
\text { Replacement of } \\
\text { the Mediator }\end{array}$} & \multicolumn{2}{|c|}{ A new mediator shall be appointed } \\
\hline & Rule (3.2) & Article (6.5) \\
\hline Joining additional & Available according to & There is no explicit \\
\hline parties/claims & Rule (4.6) & provision for that \\
\hline \multirow{4}{*}{$\begin{array}{l}\text { Conclusion / } \\
\text { Termination of } \\
\text { the mediation }\end{array}$} & $\begin{array}{l}\text { When a party withdraws } \\
\text { (Rule 5.1.d) }\end{array}$ & CRCICA (9.1) \\
\hline & $\begin{array}{l}\text { If a settlement is reached } \\
\text { (Rule 5.1.a) }\end{array}$ & CRCICA (9.c) \\
\hline & $\begin{array}{c}\text { If a settlement has not } \\
\text { been achieved (Rule } \\
5.1 . \mathrm{b}) \\
\end{array}$ & CRCICA (9.b) \\
\hline & $\begin{array}{l}\text { If the mediator informs } \\
\text { the parties that any } \\
\text { further attempts at } \\
\text { settlement seem to be } \\
\text { successful (Rule 5.1.c) }\end{array}$ & \\
\hline \multirow{2}{*}{$\begin{array}{l}\text { Settlement } \\
\text { Agreement }\end{array}$} & \multicolumn{2}{|c|}{ It is not legally binding unless both parties sign it } \\
\hline & Rule $(4.8)$ & Article (10) \\
\hline \multirow{2}{*}{$\begin{array}{l}\text { Adjournment the } \\
\text { mediation }\end{array}$} & \multicolumn{2}{|c|}{ To allow the parties to consider specific proposals } \\
\hline & Rule (4.7) & Article (9.2) \\
\hline \multirow{3}{*}{$\begin{array}{l}\text { Prohibitions for } \\
\text { the mediator }\end{array}$} & \multicolumn{2}{|c|}{$\begin{array}{l}\text { In any subsequent proceedings between the } \\
\text { parties, the mediator shall not be appointed as }\end{array}$} \\
\hline & $\begin{array}{l}\text { An adjudicator, an } \\
\text { arbitrator, an expert, or } \\
\text { any other form of } \\
\text { tribunal }\end{array}$ & $\begin{array}{l}\text { A witness, an expert, } \\
\text { a consultant, or a } \\
\text { mediator }\end{array}$ \\
\hline & Rule (8.2) & Article (12) \\
\hline \multirow{3}{*}{$\begin{array}{l}\text { Exclusion of } \\
\text { liability }\end{array}$} & \multicolumn{2}{|c|}{$\begin{array}{c}\text { The mediator is not liable for anything done or } \\
\text { omitted in the discharge of his functions as } \\
\text { mediator }\end{array}$} \\
\hline & Rule (8.4) & Article (13) \\
\hline & $\begin{array}{l}\text { However, the ICE } \\
\text { provision added, "unless } \\
\text { the act or omission is in } \\
\text { bad faith". }\end{array}$ & \\
\hline \multirow{3}{*}{$\begin{array}{l}\text { Costs of the } \\
\text { mediation }\end{array}$} & & $\begin{array}{l}\text { It has been identified } \\
\text { in four parts: }\end{array}$ \\
\hline & $\begin{array}{l}\text { Mediator's fees and } \\
\quad \text { expenses }\end{array}$ & $\begin{array}{l}\text { Administrative fees, } \\
\text { mediator's fees, any } \\
\text { expenses incurred by } \\
\text { the mediator, and any } \\
\text { expenses of the } \\
\text { appointing authority }\end{array}$ \\
\hline & Rule (8.3) & Article (14) \\
\hline
\end{tabular}

According to table III [17]; by making a comparison between ICE and CRCICA mediation rules, the following can be concluded: Both rules agree on some points such as the objective, exchange of information confidentially, legal representation, submitting a mediation request in case of no agreement in advance, and the final compromise. On the other hand, CRCICA meditation rules differ from ICE rules in the mediation commencement, which starts when the parties agree to settle the dispute through mediation procedures. According to ICE mediation commencement after the mediator is named. Besides, the mediator's selection in judicial mediation shall be, by agreement of the parties, from among the mediators registered in the mediators' list in the competent mediation administration. Besides, the ICE rules allow the inclusion of other parties or other statementsto the contested issue, while there is no explicit provision for this in the CRCICA rules. Lastly, after serving as a mediator, the mediator cannot serve as an arbitrator or a solicitor.

\section{ICE Rules}

\section{Rule 1.3}

The article added that the mediator may disclose any information, but with the express permission of the parties

\section{Rule 2.1}

The rule added that The Notice of Mediation must be supported by a short statement of the matter to be referred as well as the redress sought.

\section{Rule 4.2}

It stipulates that the mediation procedures shall start within two months of the appointment of the mediator.

\section{Rule 4.6}

This rule stipulates that any party may request that the mediation include further claims or disputes or other parties. Such requests accompany details of the contractual facts, notices and decisions concerned.

The mediator and all parties shall give such joinder their consent. Another partner shall have the same rights and obligations as the other parties to the mediation unless otherwise agreed by the parties. All other parties shall sign the agreement of the mediator.

\section{Rule 4.7}

Suppose, in the mediator's opinion, the resolution of the dispute would be assisted by a further investigation by either party or by the mediator or by an interim agreement, including some action by any party. In that case, the mediator may agree with the parties, give particulars thereof, and/or adjourn the proceedings as may be appropriate.

\section{Rule 4.8}

If an overall settlement or part of the disputed issues has been reached, the parties shall conclude a deal that includes the settlement terms. The mediator shall assist them to prepare this agreement. The mediator shall not sign this agreement as a party to that but may sign as a witness.

\section{COMPARISON OF CRCICA MEDIATION RULES AND THE EGYPTIAN DRAFT MEDIATION LAW}

Table IV shows the similarities and differences between the two systems [7] and [30]. It turns out that there is no explicit provision with specific requirements in the case of the mediator replacement in the Egyptian Mediation Draft Law. Besides, the ICE Mediation Rules characterized by that the parties may jointly request the mediator to make oral or written recommendations regarding the appropriate settlement of the dispute. ICE Mediation Rules also added two new cases to end 
the mediation: when one of the parties withdraws and when the mediator decides that no amicable settlement has been reached.

\section{SUMMARY AND CONCLUSION}

From the above, it is possible to summarize the following:

1. There are three types of mediation: ad-hoc mediation, institutional mediation, and judicial mediation.

2. Some parties resort to mediation because it guarantees the continuity of relations between the parties to the conflict by finding satisfactory solutions and preserving their interests. Besides, it provides faster dispute resolution and lower cost than judiciary and arbitration.

3. There are specific characteristics that a mediator must possess to be effective and achieve its objectives for the mediation process. Those skills facilitate the parties towards a settlement, act as a problem solver, identify common goals, and be patient.

4. The mediation process's main steps can be summarized in four steps: Mediation Agreement or Notice of Mediation, the mediator's appointment, Conduct of the mediation, and Conclusion or Termination of the mediation.

5. In agreed mediation, the mediator is chosen by agreement of the parties, while in judicial mediation, the head of the mediation department appoints him.

6. The mediation rules for both ICE and CRCICA agree on some issues, such as confidentiality, representation, the mediator's appointment, the resignation of the mediator, and settlement agreement. On the other hand, there are differences between them in some matters, such as mediation commencement and joining other parties or claims, as shown in table III.

7. The barriers which restrict the spread of mediation in the UK are a) lack of detailed understanding of the mediation process; b) insufficient preparation; c) lack of confidence among the parties; d) the mediator is inappropriate, and e) mediation is non-binding technique.

8. As discussed in the comparison of CRCICA mediation rules and the Egyptian draft mediation law section, in mediation the mediator may discuss separately with each party and take whatever he deems appropriate to bring the points of view closer. However, this is not the case in arbitration; it is not the task of the arbitration tribunal to bridge the gap between the parties to the dispute, but to settle the dispute based on evidence and witnesses and listen to the claims of each party.

9. The success of mediation depends on the goodwill of the litigants in seeking to find an amicable solution to the dispute and on the role of the mediator, who must be competent to carry out the tasks entrusted to him and be independent and impartial.

10. The main difference between mediation and arbitration is that the outcome of mediation is not imposed and only becomes binding with the consent of both parties.

Besides, it can be concluded that:

1. According to what was presented in the Egyptian draft mediation law for settling civil and commercial disputes section, since mediation is the most desirable approach to resolve disputes without affecting the relationship between the parties, it is recommended to cancel the idea of compulsory judicial mediation in the Egyptian draft mediation law, and making it optional. The judicial mediation system is the closest to litigation, and therefore it lacks the most important feature of mediation, which is to maintain relations between the parties.

Table IV: CRCICA Mediation Rules and the Egyptian Mediation Draft Law

\begin{tabular}{|c|c|c|}
\hline \\
\hline $\begin{array}{c}\text { Face of } \\
\text { Comparison }\end{array}$ & $\begin{array}{l}\text { CRCICA Mediation } \\
\text { Rules }\end{array}$ & $\begin{array}{c}\text { The Egyptian Mediation } \\
\text { Draft Law }\end{array}$ \\
\hline $\begin{array}{l}\text { Appointment of } \\
\text { the Mediator }\end{array}$ & $\begin{array}{c}\text { According to Article 6, } \\
\text { the mediator is appointed } \\
\text { by the parties' agreement } \\
\text { within } \\
14 \text { days from the date of } \\
\text { the mediation } \\
\text { commencement; } \\
\text { otherwise, the center will } \\
\text { select him from among } \\
\text { those registered in the list } \\
\text { of accredited mediators } \\
\text { with the center. }\end{array}$ & $\begin{array}{l}\text { According to Articles } 23 \\
\text { and 40, in Agreed } \\
\text { Mediation, the mediator } \\
\text { is chosen by agreement of } \\
\text { the parties, while in } \\
\text { judicial mediation, the } \\
\text { head of the mediation } \\
\text { department appoints him. }\end{array}$ \\
\hline $\begin{array}{l}\text { Commencement } \\
\text { of the Mediation }\end{array}$ & $\begin{array}{l}\text { According to Article 3, } \\
\text { mediation begins when the } \\
\text { other party agrees in } \\
\text { writing to the mediation } \\
\text { request within } 15 \text { days of } \\
\text { receiving the mediation } \\
\text { request. }\end{array}$ & $\begin{array}{c}\text { According to Article 21, } \\
\text { Agreed Mediation begins } \\
\text { when the parties to the } \\
\text { dispute agree to settle it } \\
\text { through mediation } \\
\text { procedures. }\end{array}$ \\
\hline $\begin{array}{l}\text { Replacement of } \\
\text { the Mediator }\end{array}$ & $\begin{array}{l}\text { According to Article 6, if } \\
\text { a mediator resigns, or for } \\
\text { any reason, he becomes } \\
\text { unable to perform his } \\
\text { duties, a new mediator } \\
\text { shall be appointed. }\end{array}$ & $\begin{array}{l}\text { There is no explicit } \\
\text { provision with specific } \\
\text { requirements. }\end{array}$ \\
\hline $\begin{array}{l}\text { Impartiality } \\
\text { and } \\
\text { Independence } \\
\text { of }\end{array}$ & $\begin{array}{l}\text { According to Article } 7 \text {, } \\
\text { the nominated mediator } \\
\text { submits to the Center } \\
\text { and the parties a signed } \\
\text { declaration confirming } \\
\text { his }\end{array}$ & $\begin{array}{c}\text { According to Articles } \\
2 \text { and } 3 \text {, the mediator } \\
\text { must adhere to } \\
\text { impartiality and } \\
\text { integrity and disclose } \\
\text { any }\end{array}$ \\
\hline the Viediator & $\begin{array}{c}\text { Impartiality and } \\
\text { independence and } \\
\text { discloses any facts that } \\
\text { may raise doubts. }\end{array}$ & $\begin{array}{c}\text { Circumstances that raise } \\
\text { any doubts in this } \\
\text { regard. }\end{array}$ \\
\hline $\begin{array}{l}\text { Conduct of the } \\
\text { Mediation }\end{array}$ & $\begin{array}{l}\text { According to Article } 8 \text {, } \\
\text { the rules added that the } \\
\text { parties may jointly } \\
\text { request the mediator } \\
\text { to make oral or written } \\
\text { recommendations } \\
\text { regarding the appropriate } \\
\text { settlement } \\
\text { of the dispute }\end{array}$ & $\begin{array}{l}\text { According to Articles } \\
6 \text { and 7, the mediator } \\
\text { may discuss separately } \\
\text { with each party and } \\
\text { take whatever he } \\
\text { deems appropriate to } \\
\text { bring } \\
\text { the points of view } \\
\text { closer. The parties may } \\
\text { seek the assistance of } \\
\text { experts and specialists } \\
\text { to express their opinion } \\
\text { on any of the technical } \\
\text { issues related to the } \\
\text { dispute }\end{array}$ \\
\hline $\begin{array}{l}\text { Termination of } \\
\text { the Mediation }\end{array}$ & $\begin{array}{l}\text { According to Article } 9 \text {, } \\
\text { the rules added two more } \\
\text { cases where mediation } \\
\text { ends; when one of the } \\
\text { parties withdraws or } \\
\text { when the mediator } \\
\text { decides that no amicable } \\
\text { settlement has been } \\
\text { reached }\end{array}$ & $\begin{array}{l}\text { According to Article } \\
\text { 21, on the day the } \\
\text { parties get a settlement } \\
\text { agreement or the day } \\
\text { either party announces } \\
\text { its } \\
\text { termination }\end{array}$ \\
\hline
\end{tabular}


2. It is preferable and desirable to activate the concept of preventive justice. In other words, to ensure that justice is achieved before the conflict arose by giving the right to who is due from the beginning without the need to present his right to the judiciary, by giving rights their legal force and enforcement authority, consequently contracts have their executive power.

3. Mediation is recommended as the most desirable approach to resolve disputes without affecting the relationship between the parties. However, to achieve the desired goal of its use, and for it to spread on a large scale, some obstacles must be overcome by the following: a) Choose the appropriate mediator who has the qualifications to resolve the dispute, according to what was shown in the Egyptian draft mediation law section; b) For mediation to be binding, the settlement agreement has to be signed by both parties, according to articles 23 and 36 of the draft law, Article 10 of CRCICA and Rule 4.8 of ICE; and c) Good preparation for the mediation process while providing an atmosphere of transparency, good faith and a genuine desire for settlement, according to article 2 .

4. As discussed in the comparison of CRCICA mediation rules and the Egyptian draft mediation law section, it is recommended to add some provisions to the Egyptian Mediation Draft Law to improve it such as a provision with specific requirements in case of the mediator's replacement, enable the parties to request any recommendations to resolve the dispute from the mediator, and two new cases to end the mediation to be added: when one of the parties withdraws and when the mediator decides that no amicable settlement has been reached and any further attempts at settlement seem to be successful.

5. As discussed in the comparison of CRCICA mediation rules and the Egyptian draft mediation law section, defining the concept of impartiality and independence is a large loose matter and is usually left to the judge to interpret. It is envisaged that the legislator can include certain cases in the mediation law's executive regulations, guiding the judge in inferring the impartiality and lack of independence.

6. It is recommended to add an article to the Egyptian mediation law allows any party to request that the mediation include further claims or disputes or other parties, as discussed in ICE rule 4.6.

\section{References}

[1] Abdullah, M. (2015). An Investigation of the Development of Mediation in the UK Construction Industry. D. Ph. Thesis. The University of Manchester, United Kingdom.

[2] Al Majedy, A. (2019). Judicial mediation as a way to resolve disputes. Alexandria: Dar Elgamaa Elgadida.

[3] Brooker, P. (1997). Factors which impact on the choice of alternative dispute resolution in the construction industry. Ph.D. Thesis; Oxford Brookes University,U.K.

[4] Bsieso, R. (2001). Resolving Disputes Without Litigation, Through Mediation. D. Ph. Thesis; Kennedy-Western University, USA.

[5] CEDR. (2018). The English Mediation Audit, available at: https://www.cedr.com/wpcontent/uploads/2020/01/The_Eighth_Mediation_Audit_2018.pdf
[6] Ciarb.org, accessed on 25 November, 2020. Retrieved from these links https://ciarb.org/training/pathway-courses/mediation-courses/ and https://www.ciarb.org/membership/routes-to-membership/.

[7] CRCICA. (2013). Mediation Rules. The Cairo Regional Centre for International Commercial Arbitration. Retrieved from https://www.crcica.org/rules/mediation/2013/crcica mediation rules 201 3.pdf

[8] Crcica.org, accessed on February, 2021. Retrieved from

https://crcica.org/EventDetails.aspx?ID=42

[9] Elwatannews.com, accessed on August, 2021. Retrieved from

https://www.elwatannews.com/news/details/4467235

[10] Elziny, A., et al. (2016). An expert system to manage dispute resolutions in construction projects in Egypt. Ain Shams Engineering Journal, 7(1), 57-71.

[11] Fisher, W. (2017). The use of arbitration in the construction industry in England and Wales: an evaluation of its continuing role following the Arbitration Act 1996. Ph.D. thesis; The University of Wolverhampton, U.K

[12] Gaitskell, R. (2016). Keating Construction Dispute Resolution Handbook. London: ICE Publishing.

[13] Gould, N., (2007). Mediation in construction disputes: An interim report Available at https://www.fenwickelliott.com/sites/default/files/ADR\%206\%20\%20Mediation\%20In\%20Construction\%20Disputes.pdf

[14] Gould, N., et al. (2010). Mediating Construction Disputes: An Evaluation of Existing Practice. London: Centre of Construction Law\&Dispute Resolution.

[15]Gregory-Stevens, J. (2016). Construction disputes in England: the option for mediation. Doctoral dissertation, Anglia Ruskin University.

[16] Institution of Civil Engineers. (2012). ICE Arbitration Procedure. ICE Publishing. Retrieved from https://www.ice.org.uk/ICEDevelopmentWebPortal/media/Documents/Di sciplines\%20and\%20Resources/09-2-ICE-Arbitration-procedure-2012-0430.pdf

[17] Institution of Civil Engineers. (2012). ICE Mediation/ Conciliation $\begin{array}{llll}\text { Procedure. ICE Publishing. } & \text { Retrieved from }\end{array}$ https://www.ice.org.uk/ICEDevelopmentWebPortal/media/Documents/Di sciplines\%20and\%20Resources/09-4-ICE-Mediation-Conciliationprocedure-2012-03-30.pdf

[18] Institution of Civil Engineers. (1999). Mediation and Conciliation. ICE Publishing.

[19] Ismail, Z., et al. (2010). Mediation in construction industry?. Journal of Surveying, Construction and Property.

[20] Mansour, E. and Eid, S. (2017). Mediation and the art of negotiation. Cairo: Dar Al Nahda.

[21] Marcil, J. and Thornton, N. (2008). Avoiding Pitfalls: Common Reasons for Mediation Failure and Solutions for Success. North Dakota Law Review.

[22] Marzouk, M., El-Mesteckawi, L., and El-Said, M. (2011). Dispute resolution aided tool for construction projects in Egypt. Journal of Civil Engineering and Management, 17(1), 63-71.

[23] Rajoo, S. (2010). Institutional and Ad hoc Arbitrations: Advantages and Disadvantages. The Law Review, 554.

[24] Remond, J. (2008). Adjudication in Construction Contracts. Wiley\&Sons.

[25] Roberts, K. (2007). Mediating the evaluative-facilitative debate: Why both parties are wrong and a proposal for a settlement. Loyal University Chicago Law Journal.

[26] Pickavance, J. (2016). A practical guide to construction adjudication. London: Wiley Blackwell.

[27] Stevens, J., et al. (2016). Mediation in construction disputes in England. International Journal of Law in the Built Environment.

[28] Tembo, C., et al. (2010). Practice and procedure in the mediation of construction industry disputes: An exploratory study. W113-Special Track 18th CIB World Building Congress May 2010 Salford, United Kingdom.

[29] Yiu, et al. (2007). Toward a typology of construction mediator tactics. Building and environment.

[30]Youm7.com, accessed on August, 2020. Retrieved from https://www.youm7.com/story/2013/2/12/\%D9\%86\%D9\%86\%D8\%B4\%D8\% B1-\%D9\%86\%D8\%B5-\%D9\%85\%D8\%B3\%D9\%88\%D8\%AF\%D8\%A9-

\%D9\%82\%D8\%A7\%D9\%86\%D9\%88\%D9\%86-

\%D8\%A7\%D9\%84\%D9\%88\%D8\%B3\%D8\%A7\%D8\%B7\%D8\%A9\% $9 \% 84 \% \mathrm{D} 8 \% \mathrm{AA} \% \mathrm{D} 8 \% \mathrm{~B} 3 \% \mathrm{D} 9 \% 88 \% \mathrm{D} 9 \% 8 \mathrm{~A} \% \mathrm{D} 8 \% \mathrm{~A} 9$ 
\%D8\%A7\%D9\%84\%D9\%85\%D9\%86\%D8\%A7\%D8\%B2\%D8\%B9\%D8\%A $7 \% \mathrm{D} 8 \% \mathrm{AA}-$

\%D8\%A7\%D9\%84\%D8\%AA\%D8\%AC\%D8\%A7\%D8\%B1\%D9\%8A\%D8

\%A9-

\%D9\%88\%D8\%A7\%D9\%84\%D9\%85\%D8\%AF\%D9\%86\%D9\%8A\%D8\%A

9-\%D8\%A7\%D9\%84\%D8\%AA\%D9\%89/942603

\section{Appendix \\ Accredited Mediator in the UK; CIArb}

The Chartered Institute of Arbitrators (CIArb) is a professional body serving alternative dispute resolution (ADR) practitioners' interests. The Chartered Institute of Arbitrators was established as the Institute of Arbitrators on 1 March 1915 and became registered as a charity in the United Kingdom in 1990. CIArb provides education and training for arbitrators, mediators and adjudicators. You have to complete the CIArb Mediation requirements to be qualified as a CIArb certified mediator [6]. These requirements are as follows:

1. Module 1 Mediation Training and Assessment includes six days of skill-based learning provided by qualified practical mediators. The approach uses skills that can affect personal relationships positively. When the course is completed successfully, the students will: explain the method, its advantages and disadvantages; demonstrate expertise in the core skills of the mediator; show that they can handle a mediation.

2. Module 2 Law of Obligations; this course is structured to consider both common and civil law concepts and give all practitioners a strong base. The course is intended for persons who have not previously been practicing law and want to recognize the law elements in several jurisdictions concerning civil and commercial conflict matters. It is ideal for people with a general interest in settling disputes and is necessary for people wishing to become skilled mediators.

3. Module 3 Mediation Theory and Practice; this course is designed to allow the applicant to demonstrate good academic knowledge of the field of mediation. This module is compulsory for all applicants who wish to become a Mediation Fellow and consists of two sections. Firstly, a long article on one aspect of mediation theory is completed. The word count ranges from 6000 to 7000 words and is expected to be completed by written official approval within 6 months. The second is practicing a portfolio established by candidates based on three cases they have encountered in which they have acted as lead mediators. Then, they will be invited to discuss these cases with the Director of Education \& Training.

4. English Language Competence - candidates must be trained in both written and spoken English because CIArb preparation and evaluation are carried out in English. If English is not a first language candidate, the applicants should reach at least a norm equivalent to level 7 of the International English Language Test (IELTS). CIArb offers this advice as a reference, and while no proof of this standard is needed before a course registration, candidates who do not have this English standard may be inconvenient.

5. Besides, candidates must be registered as a mediator with CIArb. To be a CIArb member, a person must either complete a CIArb training course or have the required experience, as shown in the following Fig.

\section{Accredited Mediator in Egypt; CRCICA}

To obtain a mediator accreditation certificate, a minimum of 45 hours of theoretical and practical training must be passed and successful completion of practical training. The Fundamentals of Mediation Training provides 12 hours of theoretical training towards certification of mediator accreditation by the Cairo Center.

This training is designed according to the latest international methods that adopt the approach of learning through experimentation, and its activities are based on studying the needs of the participants. The training will include several methods such as presentation, brainstorming, exercises, aids and practical applications. The training and scientific material is also characterized by the flexibility of adapting it according to the needs.

No specific academic or professional background is required. Registration is open to all professionals interested in mediation, and a minimum of two years professional experience is preferred [8]. 